\title{
Impact of COVID-19 Pandemic on Customer Satisfaction and Loyalty Index for Public Transport
}

\author{
Nur Farhana Norzelan ${ }^{1}$, Siti Zaharah Ishak ${ }^{1,2, *}$, Suria Haron ${ }^{3}$, S. Sarifah Radiah Shariff ${ }^{2,4}$, \\ Teh Zaharah Yaacob ${ }^{5}$
}

\begin{abstract}
${ }^{1}$ School of Civil Engineering, College of Engineering, Universiti Teknologi MARA, 40450 Shah Alam Selangor, Malaysia
${ }^{2}$ Malaysia Institute of Transport (MITRANS), Universiti Teknologi MARA, 40450 Shah Alam, Selangor, Malaysia

${ }^{3}$ School of Civil Engineering, Universiti Teknologi MARA Pulau Pinang Branch, 13500 Permatang Pauh, Pulau Pinang, Malaysia

${ }^{4}$ Centre for Statistics and Decision Science Studies, Faculty of Computer and Mathematical Science, Universiti Teknologi MARA, 40450 Shah Alam Selangor, Malaysia

${ }^{5}$ Azman Hashim International Business School, Universiti Teknologi Malaysia (UTM), Skudai 81310 Johor Bahru, Johor, Malaysia
\end{abstract}

Received July 21, 2021; Revised October 19, 2021; Accepted November 16, 2021

\section{Cite This Paper in the following Citation Styles}

(a): [1] Nur Farhana Norzelan, Siti Zaharah Ishak, Suria Haron, Sharifah Radiah, Teh Zaharah Yaacob, "Impact of COVID-19 Pandemic on Customer Satisfaction and Loyalty Index for Public Transport," Civil Engineering and Architecture, Vol. 10, No. 1, pp. 356-365, 2022. DOI: 10.13189/cea.2022.100130.

(b): Nur Farhana Norzelan, Siti Zaharah Ishak, Suria Haron, Sharifah Radiah, Teh Zaharah Yaacob (2022). Impact of COVID-19 Pandemic on Customer Satisfaction and Loyalty Index for Public Transport. Civil Engineering and Architecture, 10(1), 356-365. DOI: 10.13189/cea.2022.100130.

Copyright $\bigcirc 2022$ by authors, all rights reserved. Authors agree that this article remains permanently open access under the terms of the Creative Commons Attribution License 4.0 International License

\begin{abstract}
The COVID-19 outbreak is a global pandemic that is now widespread across the world. Malaysia government has implemented the Movement Control Order (MCO) or so-called massive restriction in Malaysia. The restriction amongst others includes that the public is advised to stay and work from home. Only the essential services are allowed to operate at capacity within the stipulated Standard Operating Procedures (SOP). Public transport operation is considered as essential services that need to provide people with mobility and access to employment, community resources, medical care, and recreational opportunities in communities. This study aims to identify the impact of COVID-19 pandemic on urban public transport in Kuala Lumpur, Malaysia. The objectives include: to determine the change of ridership trends, to measure the Customer Satisfaction Index (SCI) and Loyalty Index (CLI) in taking consideration of the current COVID-19 SOP provided by public transport operators. The questionnaire survey was distributed via online and received 401 respondents. The results show significant decreases in ridership and new mobility patterns emerge from public transport to private cars. The COVID-19 pandemic also impacted the CSI and CLI value for both public transport services-bus and rail within the urban public transport users. The highlights of public transport users' concern on using the public transport
\end{abstract}

during this pandemic will be discussed.

Keywords COVID-19 Pandemic, Public Transport, Customer Satisfaction Index (SCI), Customer Loyalty Index (CLI)

\section{Introduction}

Malaysia had detected their first case of COVID-19 outbreak on 25th January 2020 and the first Malaysian was confirmed with COVID-19 outbreak on the 4th February 2020. The number of reported positive cases grew rapidly in March 2020 and Malaysia confirmed two (2) COVID-19 related deaths on 17th March. As the number of positive cases increased relatively high on March 16, the Prime Minister of Malaysia announced a Movement Control Order (MCO) in order to reduce the rapid spread of COVID-19 [2].

Nevertheless, the current easing of the MCO or so-called massive restriction in Malaysia presents a threat to public transportation. Public transportation system is one of the most important components that provide people with mobility and access to employment, community resources, 
medical care, and recreational opportunities in communities. Public transportation also helps to reduce various problems such as traffic congestion, increased travel time, and environmental pollution due to the dependence of the community on private vehicles [9].

There are many challenges and difficulties during the COVID-19 pandemic. The rail services had to run at half of normal capacity and bus services were reduced to $30 \%$ of normal capacity due to the Standard Operating Procedure guideline that must be followed during the Movement Control Order (MCO) [1]. The impact of pandemics on ridership can be seen clearly from the reported data from major public transport operators in Malaysia. The trends of ridership show during the normal pre-MCO Rapid KL can reach 750,000 passengers daily but drastically down to 200,000 people a day during the MCO. The total ridership of bus services under the Rapid Bus has decreased from 429,000 daily before the MCO in March to only 180,000 daily riders which decreased by $58 \%$ [7].

Based on Fig. 1, the 'U-Shape' recovery forecast the rail and bus services ridership dropped by nearly $85 \%$ to $95 \%$ during the phase 1 Movement Control Order (MCO) period from 18th March till 3rd May 2020 compared to the original forecast. During the preventive measure phase 5 Conditional Movement Control Order (CMCO) from 4th May till 9th June 2020, daily ridership dropped by nearly $60 \%$ to $85 \%$ relative to normal ridership prior to the COVID-19 outbreak. The assumption during RMCO 10th June till 31 st August 2020, the ridership dropped by $30 \%$ to $60 \%$ relative to normal ridership but to be expected 100 percent capacity allowed for rail and bus services and operation back to normal.

\section{U-SHAPE RECOVERY FORECAST-RAIL \& BUS RIDERSHIP}

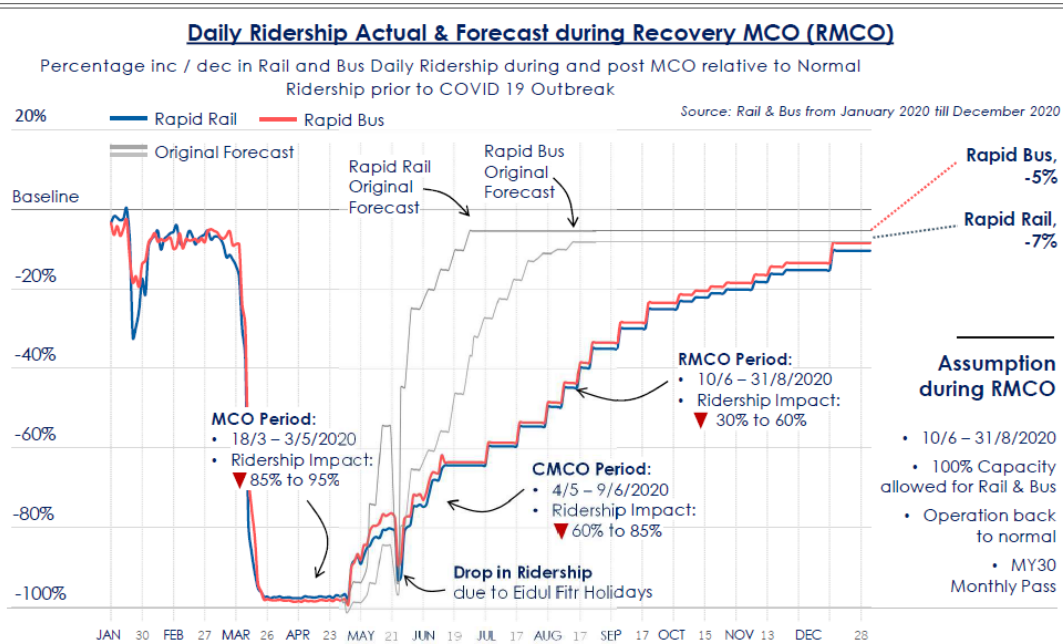

Figure 1. ' U-Shape' Recovery forecast-rail and bus ridership [7]

\section{\begin{tabular}{ll|l|l|l} 
Ridership ('000) & 2020 & 2019 & Average Weekday
\end{tabular}}

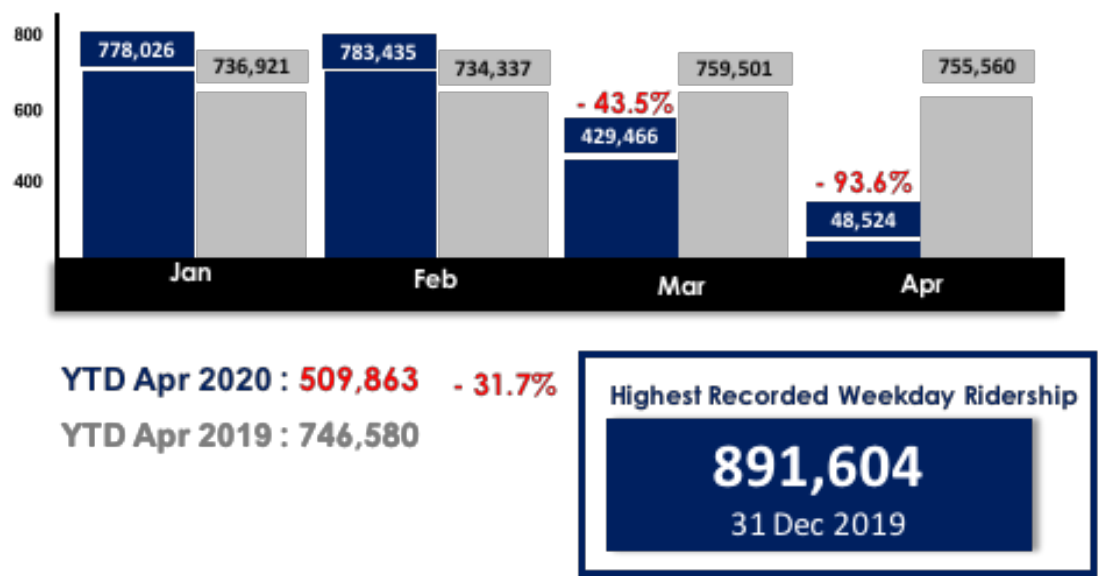

Figure 2. Rapid rail ridership [7] 
Rapid rail ridership has taken a hit from the COVID-19 outbreak where according to data collated by Prasarana Malaysia Berhad in Figure 1.2, rapid rail (LRT, MRT, MONORAIL) ridership has decreased significantly. Prior to COVID-19, rapid rail by Prasarana Malaysia Berhad Services recorded the highest weekday ridership at around 891,604 by the end of December 2019.

With many residents working from home (WFH) and rail services operate at half of the normal capacity during the preventive measures MCO period, the average weekday transit demand shows that ridership in March had already fallen by 759,501 ridership before the pandemic to 429,466 during the pandemic. Due to the MCO period with people at home, ridership in April was down a massive 93.6 percent on the year before. Rapid rail ridership has plunged by 31.7 percent from 746,580 Year to Date (YTD) April 2019 to 509,863 YTD April 2020.

Many regular public transport passengers have made drastic decisions to change their mobility patterns from public transport to private vehicles such as private amidst the COVID-19 health threat as a safety measure and even rethink to consider whether it is safe or not to take public transportation amid the COVID-19 pandemic [5]. Many unhealthy stereotypes on the believed that public transport can be the major spreader COVID-19 should be avoided.

Thus the public transport operators should gain public transport users trust by providing major priority on customer's safety and health. The relationship between trust and satisfaction was discussed in taking consideration of COVID-19 Pandemics. The implementation of COVID-19 protocol or Standard Operating Procedures (SOP) was significantly effected customer trust thus effected customer satisfaction and loyalty [6]. According to public-health experts, public transportation may pose a relatively low risk of infection if passengers follow the guideline by wearing masks and adhere social-distancing. However, this risk may also depend on the passenger's seat and how long the passenger is traveling [8]. The concerns arising from this discussion may also impact the travel pattern, customer satisfaction and loyalty amongst public transport users during this COVID-19 pandemic and therefore will reduce the public transport ridership in Malaysia.

This paper aims to study the impact of COVID-19 pandemics on public transport sectors in Malaysia. The objectives include a) to identify the current ridership trend b) to determine the factors affecting the choice of regular public transit customers to change their mobility patterns during the COVID-19 pandemic and c) to measure the Customers Satisfaction Index (CSI) and Loyalty Index (CLI) of public transport users during the COVID-19 pandemic.

\section{Methods and Discussion}

The primary focus of this study was on the primary data obtained from questionnaire surveys. The data were gathered via online and disseminated to public transport users. The scope of this study covers Kuala Lumpur and Selangor areas and therefore covers bus and rail services within Central Business District (CBD) areas. The concentration of discussion was given to measure the CSI and CLI.

\subsection{Methodology Flowchart}

Fig. 3 displayed the research methodology flowchart used in this study. The formulation of the problem statements leads to several objectives that were set to be obtained in this study. The source of early information was gathered from secondary data collection that was obtained from various sources e.g journal articles. The major data obtained from this study were gathered from primary data collection via questionnaire survey. The sample size was obtained using Raosoft Survey tools. The sample size suggested in this study is about 400 respondents. The data gathered were cleaned, sorted, categorized and coded before several analyses conducted using the Statistical Package for Social Sciences (SPSS) that was used as an analysis tool in this study. 
1. STUDY ON THE IMPACT OF COVID-19 PANDEMIC ON URBAN PUBLIC TRANSPORT SECTOR IN MALAYSIA

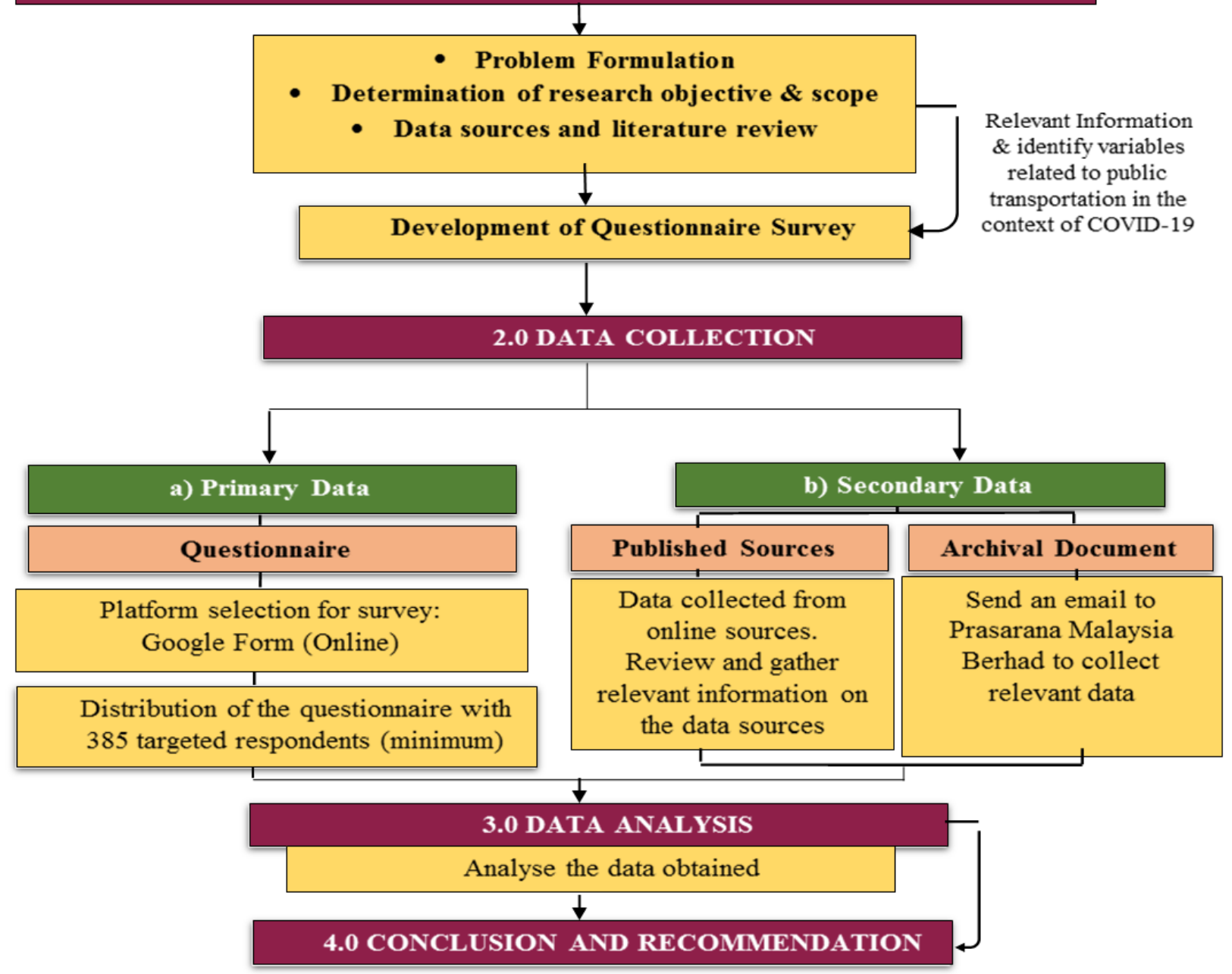

Figure 3. Research methodology flowchart

\subsection{The Questionnaire Survey Design}

The questionnaire was designed to achieve objectives as stipulated in this study. The section includes:

i. $\quad$ Section A: Survey Information

ii. Section B: Demographic profile

iii. Section C: Travel Information

iv. Section D: Customer Satisfaction

v. Section E: Customer loyalty

vi. Section F: Recommendation

The Likert Scale used in this study provides the description in five (5) points measuring the following a) Customer Satisfaction from scale 1 - very dissatisfied to scale 5 - very satisfied b) Customer Loyalty from scale 1 - strongly disagree to 5 - strongly agree).

\subsection{Data Analysis}

A descriptive analysis was carried out to compile a set of data that represents the entire population or a sample size that helps the researcher to understand the analysed data through tables, charts, graphs, and general discussion [10]. Pearson correlation was used to establish the relationship between the variables. Pearson correlation examines the occurrence of a statistically significant correlation between two variables (given by a p-value) as well as strength (given by the coefficient $r$ between -1 and +1 ). A positive correlation indicates a positive relationship that increases the values of one variable as another variable's values increase. On the other hand, a negative correlation indicates a negative relationship that decreases the values of one variable as another variable's values decrease [3].

\section{Result}

The following discussion reflects the feedback from 401 respondents participating in this survey that consists of $22 \%$ bus users and $78 \%$ rail users. The demographic profiles were tabulated in Table 1. 
Table 1. Demographic Profile

\begin{tabular}{|c|c|c|c|}
\hline Item & Particular & Frequency & $\begin{array}{c}\text { Percentage } \\
\text { (\%) }\end{array}$ \\
\hline \multirow{3}{*}{ Gender } & Female & 233 & 58.1 \\
& Male & 168 & 41.9 \\
& Total & 401 & 100 \\
\hline \multirow{3}{*}{ Citizenship } & Malaysian & 401 & 100 \\
& Total & 401 & 100 \\
\hline & Under 18 & 2 & 5 \\
& $18-35$ & 280 & 69.8 \\
& $36-55$ & 110 & 27.4 \\
& 56 above & 9 & 2.2 \\
& Total & 401 & 100 \\
\hline \multirow{5}{*}{ Occupation } & Government & 107 & 26.7 \\
& sector & 17 & 4.2 \\
& Housewife & 129 & 32.2 \\
& Private sector & 8 & 2.0 \\
& Retiree & 78 & 19.5 \\
& Self-employed & 52 & 13.0 \\
& Student & 10 & 2.5 \\
& Unemployed & 401 & 100 \\
\hline & Total & & \\
\hline
\end{tabular}

The respondents in this survey consisted of $58.1 \%$ female and $41.9 \%$ male - all respondents were Malaysian citizens. The highest percentage of group age that responded to the survey was $18-35$ year $(69.8 \%)$ followed by $36-55$ year $(27.4 \%)$. By type of occupation, the highest group of respondents works in the private sector $(32.2 \%)$, followed by government sector $(26.8 \%)$ and self-employed (19.5\%).

\subsection{Public Transportation Ridership Trend during COVID-19}

Public transport user feedback on their travel pattern before and during COVID-19 is shown in Table 2. The parameters measured were the trip frequencies during weekends and weekdays. Trip frequency of 'more than 5 times a week' recorded a significant decrease from $72 \%$ before the pandemic to $31 \%$ during the pandemic. There is a significant change of travel pattern during weekends from 'once in the week' $(72 \%)$ before pandemics to 'one in the while' $(76 \%)$ during pandemics.

Table 2. Travel Information (Weekdays and Weekends Trip Frequency)

\begin{tabular}{|c|c|c|c|}
\hline Item & Particular & Frequency & Percentage \\
\hline & $>=5$ times a week & 289 & 72.1 \\
Weekdays trip frequency & 3 times a week & 35 & 9.7 \\
before the Covid-19 & 4 times a week & 39 & 1.7 \\
pandemic & Once a week & 7 & 3.5 \\
& Once in a while & 14 & 4.2 \\
& Twice a week & 17 & 100 \\
\hline & Total & 401 & 30.9 \\
& > 5 times a week & 124 & 34.4 \\
Weekdays trip frequency & 3 times a week & 138 & 4.7 \\
DURING the Covid-19 & 4times a week & 7 & 5.7 \\
pandemic & Never & 19 & 4.2 \\
& Once a week & 23 & 18.2 \\
& Once in a while & 17 & 100 \\
\hline Twice a week & Total & 73 & 1.2 \\
Weekends trip frequency & Never & 401 & 71.8 \\
BEFORE the Covid-19 & Once a week & 5 & 4.7 \\
pandemic & Once in a while & 288 & 22.2 \\
& Twice a week & 19 & 100 \\
\hline
\end{tabular}


Due to several phases of MCO implemented by the Government, the encouragement of 'new norm' style of working and learning was introduced. Table 3 presents the frequency and percentage of the Work from Home (WFH) and Online Distance Learning (ODL). About 58.9\% respondents WFH and 99.6\% ODL, the result of WFH reflects the higher percentage of respondent works at Private sectors, thus may reflect categories of essential services (e.g. frontlines). All levels of education were encouraged to conduct via online modes. These two (2) major contributors as public transport users reflect the ridership numbers and travel pattern especially at CBD.

Table 3. Travel Information (WFH and ODL Frequency)

\begin{tabular}{|c|c|c|c|}
\hline Item & Particular & Frequency & Percentage \\
\hline Work from Home & No & 150 & 41.4 \\
(WFH) & Yes & 212 & 58.6 \\
& Total & 362 & 100 \\
\hline Online Distance & No & 1 & 0.4 \\
Learning & Yes & 246 & 99.6 \\
(ODL) & Total & 247 & 100 \\
\hline
\end{tabular}

The first-miles and end-miles trips are also indicating the difference in travel patterns before and during pandemics. Table 4 described respondent's feedback on the selection of transport modes getting to and from public transport transit stations or bus stops. Before pandemics, most public transport users were using buses $(66.8 \%)$, followed by LRT/MRT/Monorail (25.7\%) for their first-miles trips. For end-miles, the preferences are bus (58.6\%) and followed by Taxi/E-Hailing services (36.2\%) as transport modes. The pattern changes during pandemics that public transport users prefer to take taxi/E-Hailing (63.1\%) services for their first-miles modes and use their own cars $(91 \%)$ to reach their final destination. This pattern shows that the public transport users were very much concerned about the spread of COVID-19 in relation to their travelling. Therefore, the next section will discuss further the factors that are associated with the public transport users concerned factors.

Table 4. Travel Information (The First and Last-Mile Trips)

\begin{tabular}{|c|c|c|c|}
\hline Item & Particular & Frequency & Percentage (\%) \\
\hline $\begin{array}{l}\text { To the station from house } \\
\text { before the Covid-19 } \\
\text { pandemic }\end{array}$ & $\begin{array}{c}\text { Bicycle } \\
\text { Bus } \\
\text { LRT/MRT/Monorail } \\
\text { Motorcycle } \\
\text { Private Car (Own Car) } \\
\text { Taxi/E-Hailing Car (i.e: Grab) Walking } \\
\text { Total }\end{array}$ & $\begin{array}{c}0 \\
268 \\
103 \\
2 \\
17 \\
9 \\
2 \\
401\end{array}$ & $\begin{array}{c}0 \\
66.8 \\
25.7 \\
0.5 \\
4.2 \\
2.2 \\
0.5 \\
100.0\end{array}$ \\
\hline $\begin{array}{c}\text { To the station from your } \\
\text { house during the Covid-19 } \\
\text { pandemic }\end{array}$ & $\begin{array}{c}\text { Bicycle } \\
\text { Bus } \\
\text { LRT/MRT/Monorail } \\
\text { Motorcycle } \\
\text { Private Car (Own Car) } \\
\text { Taxi/E-Hailing Car (i.e: Grab) Walking } \\
\text { None } \\
\text { Total }\end{array}$ & $\begin{array}{c}1 \\
40 \\
75 \\
2 \\
26 \\
253 \\
2 \\
2 \\
401\end{array}$ & $\begin{array}{c}0.2 \\
10.0 \\
18.7 \\
0.5 \\
6.5 \\
63.1 \\
0.5 \\
0.5 \\
100\end{array}$ \\
\hline $\begin{array}{l}\text { Exit the station before the } \\
\text { Covid-19 pandemic }\end{array}$ & $\begin{array}{c}\text { Bicycle } \\
\text { Bus } \\
\text { LRT/MRT/Monorail } \\
\text { Motorcycle } \\
\text { Private Car (Own Car) } \\
\text { Taxi/E-Hailing Car (i.e: Grab) Walking } \\
\text { Total }\end{array}$ & $\begin{array}{c}0 \\
235 \\
5 \\
1 \\
13 \\
145 \\
2 \\
401 \\
\end{array}$ & $\begin{array}{c}0 \\
58.6 \\
1.2 \\
.2 \\
3.2 \\
36.2 \\
0.5 \\
100.0 \\
\end{array}$ \\
\hline $\begin{array}{l}\text { Exit the station during the } \\
\text { Covid-19 pandemic }\end{array}$ & $\begin{array}{c}\text { Bicycle } \\
\text { Bus } \\
\text { LRT/MRT/Monorail } \\
\text { Motorcycle } \\
\text { Private Car (Own Car) } \\
\text { Taxi/E-Hailing Car (i.e: Grab) Walking } \\
\text { None } \\
\text { Total }\end{array}$ & $\begin{array}{c}0 \\
6 \\
1 \\
6 \\
365 \\
19 \\
3 \\
1 \\
401\end{array}$ & $\begin{array}{c}0 \\
1.5 \\
0.2 \\
1.5 \\
91.0 \\
4.7 \\
0.2 \\
1 \\
100.0\end{array}$ \\
\hline
\end{tabular}




\subsection{Factors of Change in Mobility Patterns during COVID-19}

Table 5 presents the combination of factors that contribute to public transport user mobility patterns during pandemics. Nearly half of the respondents believed that the public transportation environment is at high risk for the COVID-19 contagion. In terms of a combination of factors, $44.9 \%$ of the respondents were afraid to take public transport during the pandemic as they believed and have the perception that public transport is riskier in spreading the virus than private vehicles. The respondents feel uncomfortable being in crowded spaces and confined areas. The level of comfort expressed their concern of SOP implemented by public transport operators.

Table 5. Travel Information (Factors of Change in Mobility Patterns)

\begin{tabular}{|c|c|c|}
\hline Item & Frequency & Percentage (\%) \\
\hline $\begin{array}{c}\text { Afraid to take PT during pandemic as believe in the perception of PT is riskier than private } \\
\text { vehicles / As a safety measure / Uncomfortable in crowded areas and confined in limited space / } \\
\text { Uncomfortable with the Standard Operating Procedure (SOP) in PT }\end{array}$ & 180 & 44.9 \\
\hline $\begin{array}{c}\text { Afraid to take PT during pandemic as believe in the perception of PT is riskier than private } \\
\text { vehicles / As a safety measure }\end{array}$ & 27 & 6.7 \\
\hline $\begin{array}{c}\text { Afraid to take PT during pandemic as believe in the perception of PT is riskier than private } \\
\text { vehicles / As a safety measure / Uncomfortable in crowded areas and confined in limited space }\end{array}$ & 19 & 4.7 \\
\hline $\begin{array}{c}\text { Afraid to take PT during pandemic as believe in the perception of PT is riskier than private } \\
\text { vehicles / As a safety measure / Uncomfortable with the Standard Operating Procedure (SOP) in } \\
\text { PT }\end{array}$ & 64 & 16 \\
\hline As a safety measure & 25 & 6.2 \\
\hline As a safety measure / Uncomfortable in crowded areas and confined in limited space & 70 & 17.5 \\
\hline $\begin{array}{c}\text { As a safety measure / Uncomfortable in crowded areas and confined in limited space / } \\
\text { Uncomfortable with the Standard Operating Procedure (SOP) in PT }\end{array}$ & 16 \\
\hline Total & $\mathbf{4 0 1}$ & $\mathbf{1 0 0}$ \\
\hline
\end{tabular}

\subsection{Customer Satisfaction of Standard Operating Procedure (SOP)}

Table 6 presents the comparison means and standard deviations on each parameter related to public concern on the safety measures taken by operators. The Likert-scale used in this survey ranges from 1-Very Dissatisfied to 5 Very Satisfied.

There are eight (8) parameters that relate with social distancing, face mask wearing, visible hygiene measures, information provided to the public on the importance of safety and health related to COVID-19 via signages and announcements, avoiding crowded places and gathering in groups, and cashless transactions.

The result shows the same elements measured for both major transport operators. In general, similar patterns were obtained for both services. Public transport users give higher rating to parameter 5 - 'public transport operators provide signage to encourage the application of face mask and use of hand sanitizer' (Mean = 3.29) and parameter 6 'provide public announcement on the important of wearing face mask and prioritising cleanliness' (Mean $=3.29)$ for PRASARANA services. The same highest parameters 5 $($ mean $=3.30)$ and $6($ mean $=3.26)$ were obtained for KTMB. For both services, the lowest score obtained was parameter
7 - 'the passengers avoid gathering in groups and stay out of crowded spaces when it is possible especially at transit stations and stops' that obtain Mean $=2.79$ for PRASARANA services and Mean $=2.73$ for KTMB respectively. Parameter 9 - I will feel confident to use public transport if proper SOP is implemented. Mean $=4.14$ for PRASARANA and Mean $=4.15$ for KTMB. This value indicates that $83 \%$ of road users will feel confident using public transport if proper SOP is implemented throughout public transport services. Overall, in taking consideration of the existing implementation of SOP in public transport services for both PRASARANA and KTMB services, the average result obtained for Customers Satisfaction Index is 60.5 .

\subsection{Customer Loyalty Index (CLI)}

The customer loyalty index indicates the degree on how much the customer is loyal to use public transport services. In this case, the value of the CLI obtains in taking consideration of pandemic impact to public transport sectors. The transport user feedback is stipulated in Table 7. The Likert-scale used in these surveys from 1- Strongly Disagree to 5 - Strongly Agree. 
Table 6. Mean and Standard Deviation of Scores on Customer Satisfaction of SOP

\begin{tabular}{|c|c|c|c|c|}
\hline Statement & $\begin{array}{c}\text { Prasarana } \\
\text { Mean }\end{array}$ & $\begin{array}{l}\text { Prasarana } \\
\text { Std.Dev }\end{array}$ & $\begin{array}{c}\text { KTMB } \\
\text { Mean }\end{array}$ & $\begin{array}{c}\text { KTMB } \\
\text { Std. } \\
\text { Dev. }\end{array}$ \\
\hline $\begin{array}{l}\text { Public transport operators provide marking of seats and standing } \\
\text { locations for passengers to maintain requisite social distancing. }\end{array}$ & 3.06 & 0.355 & 3.06 & 0.348 \\
\hline Public transport users follow social distancing guidelines. & 3.03 & 0.359 & 3.02 & 0.327 \\
\hline $\begin{array}{l}\text { Public transport operators encourage mask-wearing in public } \\
\text { transport. }\end{array}$ & 3.12 & 0.459 & 3.05 & 0.335 \\
\hline $\begin{array}{c}\text { Mask-wearing, social distancing, and visible hygiene measures in } \\
\text { public transport are all seen as reassuring. }\end{array}$ & 3.03 & 0.359 & 3.02 & 0.335 \\
\hline $\begin{array}{l}\text { Public transport operators provide signage to encourage the } \\
\text { application of facemask and use of hand sanitizer. }\end{array}$ & 3.29 & 0.536 & 3.30 & 0.536 \\
\hline $\begin{array}{l}\text { Provide public announcement facilities on the rail about the } \\
\text { importance of wearing a face mask and prioritizing cleanliness. }\end{array}$ & 3.29 & 0.527 & 3.26 & 0.482 \\
\hline $\begin{array}{l}\text { The passengers avoid gathering in groups and stay out of crowded } \\
\text { space when possible, especially at transit stations and stops. }\end{array}$ & 2.79 & 0.543 & 2.73 & 0.511 \\
\hline $\begin{array}{l}\text { The operators encourage online ticket purchases and usage cards } \\
\text { non-cash transactions such as monthly passes and Touch n Go. }\end{array}$ & 3.08 & 0.349 & 3.09 & 0.341 \\
\hline
\end{tabular}

Table 7. Mean and Standard Deviation of Scores on Customer Loyalty Index

\begin{tabular}{|c|c|c|c|c|}
\hline Statement & $\begin{array}{c}\text { Prasarana } \\
\text { Mean }\end{array}$ & $\begin{array}{c}\text { Prasarana } \\
\text { Std.Dev }\end{array}$ & $\begin{array}{c}\text { KTMB } \\
\text { Mean }\end{array}$ & KTMB Std.Dev \\
\hline $\begin{array}{c}\text { I will continue my journey by PT } \\
\text { although there are strict SOP } \\
\text { guidelines that must be followed. }\end{array}$ & 2.64 & 0.657 & 2.61 & 0.569 \\
\hline $\begin{array}{c}\text { I will continue to use PT even while } \\
\text { still in the pandemic. }\end{array}$ & 1.90 & 0.883 & 1.73 & 0.651 \\
\hline $\begin{array}{c}\text { The PT services are the } \\
\text { transportation I plan to use after the } \\
\text { outbreak ends }\end{array}$ & 3.08 & 0.372 & 3.00 & 0.100 \\
\hline
\end{tabular}

The parameter of CLI measuring parameter 1- the willingness of public transport users to continue using public transport although there are strict SOP guidelines need to be followed. Parameter 2 - the willingness to continue using public transport even while still in pandemic and parameter 3 - willingness to continue using public transport after the outbreak ends.

The result has obtained a similar pattern of feedback for both PRASARANA and KTMB services in taking into consideration three (3) different situations. For PRASARANA, the public transport user considering to continue using the services with Mean $=1.90$ and increases slightly the agreement to continue using the service even there are strict SOP must be followed (Mean= 2.64). Meanwhile for KTMB services, the public transport user considering to continue using the services with Mean $=1.73$ and increases slightly the agreement to continue using the service even there are strict SOP must be followed (Mean= 2.61).

In consideration the outbreak ends, the public transport users will continue using the public transport services offered by PRASARANA and KTMB with the CLI of 62 and 60 respectively. The result has shown that the public transport will remain significant as their mode of transport in considering various situations as measured in the study.

\subsection{Correlation Analysis}

Table 8. Pearson's Correlation Coefficient

\begin{tabular}{|c|c|c|c|c|}
\hline & & $\begin{array}{c}\text { Ridership } \\
\text { Trend }\end{array}$ & $\begin{array}{l}\text { CSI with } \\
\text { the SOP }\end{array}$ & CLI \\
\hline \multirow{3}{*}{$\begin{array}{c}\text { Ridership } \\
\text { Trend }\end{array}$} & $\begin{array}{l}\text { Pearson } \\
\text { Correlation }\end{array}$ & 1 & $.439^{* *}$ & $.480^{* *}$ \\
\hline & Sig. (2-tailed) & & .000 & .000 \\
\hline & $\mathrm{N}$ & 401 & 401 & 401 \\
\hline \multirow{3}{*}{$\begin{array}{c}\text { Customers } \\
\text { Satisfaction } \\
\text { with the SOP }\end{array}$} & $\begin{array}{l}\text { Pearson } \\
\text { Correlation }\end{array}$ & $.439^{* *}$ & 1 & $.594^{* *}$ \\
\hline & Sig. (2-tailed) & .000 & & .000 \\
\hline & $\mathrm{N}$ & 401 & 401 & 401 \\
\hline \multirow{3}{*}{$\begin{array}{l}\text { Customers } \\
\text { Loyalty Index } \\
\text { (CLI) }\end{array}$} & $\begin{array}{l}\text { Pearson } \\
\text { Correlation }\end{array}$ & $.480^{* *}$ & $.594^{* *}$ & 1 \\
\hline & Sig. (2-tailed) & .000 & .000 & \\
\hline & $\mathrm{N}$ & 401 & 401 & 401 \\
\hline
\end{tabular}

**. Correlation is significant at the 0.01 level (2-tailed).

Further analysis was conducted using Pearson correlation in Table 8, to examine the occurrences of a statistically significant correlation between two variables (given by a p-value) as well as strength (given by the coefficient $r$ between -1 and +1 ). If the finding is 
significant, we presume that there is a connection [3]. The correlation analysis focuses on the correlation connection among the independent variable ridership trend, customer satisfaction with the SOP and Customer Loyalty Index (CLI). The Pearson's coefficient of correlation (r) is used as an indicator of the association strength and relationship among the two variables.

The Pearson correlation coefficient shows there is a significant low positive correlation between ridership trend and Customer Satisfaction with the SOP $(r=.439, \mathrm{p}<.01)$. The Pearson correlation coefficient between ridership trend and Customer Loyalty Index (CLI) shows there is a significant low positive correlation $(\mathrm{r}=.480, \mathrm{p}<.01)$. However, the analysis has shown that the customer satisfaction and Customer Loyalty Index (CLI) show a significant moderate positive correlation $(r=.594, p<.01)$ based on this public transport user feedback.

\section{Discussion}

The COVID-19 pandemic had significant impacts on ridership trends as well as the operations and provision of public transport services. The current COVID-19 pandemic situation could pose challenges and major impacts to public transportation, even if the virus has subsided. This study has found that public transport users believe that the public transportation environment is at high risk for the COVID-19 contagion. Few suggestions based on the findings of the satisfaction towards the current SOP implemented by the public transport operators will be discussed. The suggestion can be considered to gain the confidence of public transport users in using public transport services even during this COVID-19 pandemic.

Public transport operators are suggested to give serious attention to keeping passengers safe and feel safe at all times. Information about the actions taken by public transport operators in combating COVID-19 should be clearly communicated and provided within the services via official website, social media mediums to reach public transport users. This may gain public transport users confidence in continuing using public transport even at this difficult situation.

Safe work procedures for the prevention of COVID-19 need to be emphasized by ensuring all public transport users and the public transport operator's staff did the health screening before entering public transport premises especially before starting the work for staff. The frequency of disinfection services may need to be increased in order to minimize transmission on public transport. Schedule disinfection services e.g. timetable should also be displayed and announced to public transport users.

Moreover, public transportation requires an action plan regarding Standard Operating Procedure (SOP) as more people are only moderately satisfied with SOP in public transport. The public transport operators must be providing hand sanitizer and hand washing facilities to improve public transport users confidence using public transport services.

Both public transport users and operators are required to sanitize their hands and are required to wear face masks at all times within the public transport premises. Transport operators need to ensure enabling physical distancing in public transport and stations by marking $2 \mathrm{~m}$ spots. Using technology such as contactless systems, and automated sanitization contributes to a better public transport system that promotes better health and safety.

Proactive action from public transport operators is required, knowing the fact that all SOP is implemented, the strict enforcement should always be in place, continues reminders should be announces and places in all media (e.g. social media) thus public transport user will be more aware, well informed and have a perspective that the operators really care on public transport users safety.

\section{Conclusions}

This paper highlighted the factors affecting the choice of regular public transit customers to change their mobility patterns during the COVID-19 pandemic. Public transport users preferred to self-drive amidst the COVID-19 pandemic and started to avoid public transportation as a safety measure and they believed in the perception that public transport is riskier than private vehicles. On the other hand, people with access to a car, began to drive more in response to avoid crowded and confined/limited spaces within rail and bus services.

This study measured the Customer Satisfaction Index (CSI) in taking consideration of all SOP implemented by the public transport operators. The result of CSI obtained on average is 65 . This value indicates lower satisfaction compared with CSI during normal services. The value for Customer Loyalty Index (CLI) obtained on average is 37. The Pearson correlation coefficient analysis has found out that there is significant moderate positive correlation between the current CSI value obtained with the CLI. The value obtained for both CSI and CLI is very much related with the impact of COVID-19 pandemic. This result indicates that the greater the customer satisfaction of the SOP for public transport could potentially lead to the greater value of the Customer Loyalty Index (CLI).

This can be clearly seen from the perspective that public transport users are aware and always taking safety measures in their current mobility needs especially with public transport to avoid the 3Cs-Crowded places, Close contact, Confines and enclosed spaces. Proactive measures should be implemented aggressively by public transport operators to gain public transport users and local community confidence in using public transport even during this pandemic and continue using the services in 
the future.

\section{Acknowledgments}

We would like to express our gratitude and appreciation to Malaysia Institute of Transport (MITRANS), UiTM under VanGuard grant in supporting this paper submission. Special thanks to the School of Civil Engineering, College of Engineering, UiTM in assisting students in completing their Final Year Project (FYP).

\section{REFERENCES}

[1] Abdullah, M. F. (2020). Normal Baharu: Cabaran dan Peluang Pengangkutan Awam. Astro Awani, 1-8. https://www.astroawani.com/berita-malaysia/normal-bahar u-cabaran-dan-peluang-pengangkutan-awam-242186

[2] Elengoe, A. (2020). COVID-19 outbreak in Malaysia. Osong Public Health and Research Perspectives, 11(3), 93100. https://doi.org/10.24171/j.phrp.2020.11.3.08

[3] Frost, J. (2018). Statistics by Jim. Statistics by Jim, 1-29. https://online210.psych.wisc.edu/wp-content/uploads/PSY210_Unit_Materials/PSY-210_Unit01_Materials/Frost_Blo g 2020.pdff
[4] Https, M., Hmetro, W., \& My, C. (2020c). Waktu operasi pengangkutan awam dihadkan [METROTV]. 1-6. https://www.hmetro.com.my/mutakhir/2020/03/558284/wa ktu-operasi-pengangkutan-awam-dihadkan-metrotv

[5] Jenelius, E., \& Cebecauer, M. (2020). Impacts of COVID-19 on public transport ridership in Sweden: Analysis of ticket validations, sales and passenger counts. Transportation Research Interdisciplinary Perspectives, 8(July), 100242. https://doi.org/10.1016/j.trip.2020.100242

[6] Kospandani, R. \& Wahyudi, L. (2020) Public Transport Trust and Satisfaction During the COVID-19 Pandemics: Study on Electric Train Services in KAI Commuter Region 6 Yogyakarta International Journal of Economics, Business and Management Research, ISSN: 2456-7760

[7] Prasarana Malaysia Berhad (2020), Key Challenges and Impact of the Covid-19 Pandemic on Public Transport, Transportation Webinar Series 3, June 2020.

[8] Schwartz, S. (2020). Public Transit and COVID-19 Pandemic: Global Research and Best Practices. 35. https://www.apta.com/wp-content/uploads/APTA_Covid_B est_Practices_09.29.2020.pdf

[9] Su, Y., Liu, X., \& Li, X. (2020). Research on Traffic Congestion Based on System Dynamics: The Case of Chongqing, China. Complexity, 2020. https://doi.org/10.1155/2020/6123896

[10] Varsha, A. V., George, G., \& Sahajanandan, R. (2017). Lutembacher syndrome: Dilemma of doing a tricuspid annuloplasty. Annals of Cardiac Anaesthesia, 20(4), 456458. https://doi.org/10.4103/aca.ACA_36_17 